tals were hollow, the canal coinciding as nearly as could be judged with the longitudinal axis of the crystals. The exact conditions necessary for the production of such hollow crystals have not been ascertained. Only two similar cases of crystallization have been reported, so far as I could find. ' The periodide is only slightly soluble in cold benzene; more freely in hot. It is quite soluble in carbon disulphide. It is decomposed by alcohol and ether. When dry, and placed in a bottle, it remains unchanged for a long time; but when exposed to the air it gradually loses iodine. It melts at $\mathrm{I} 2 \mathrm{I}^{\circ}-\mathrm{I} 22^{\circ} \mathrm{C}$.

A sample was gently heated at $40^{\circ}-45^{\circ} \mathrm{C}$. for some time, until the color changed to a dark gray. The residue was recrystallized from petroleum ether, and by its melting-point ( $152^{\circ} \mathrm{C}$.) and all other properties was identified as bromtriphenylmethane.

Attempts to determine the molecular weight by the cryoscopic method did not give satisfactory results.

I wish to thank Mr. W. H. Hess, who kindly helped me in this work.

ANN ARBOR, MITHIGAN.

\title{
NITRIC NITROGEN PRODUCED BY THE PEA.
}

\author{
BY J. L. BEESON. \\ Received August $15,1898$.
}

$\mathrm{T}$ has been long known that the leguminous plants contain
more nitrogen than they get from the soil, hence their almost universal use as soil improvers.

Hellriegel and Wilfarth in I886 showed that the leguminosæ would not grow in sterilized sand for lack of nitrogen, but that if the sand be inoculated with water, in which the roots of a well developed plant of the variety experimented on had been soaked, the plant would at once begin to grow, rapidly developing root tubercles. Microscopic investigation showed the presence of bacteria in these tubercles. These micro-organisms are now cultivated and sold under the name of "Nitragin" for the purpose of inoculating sterile soils, that is, soils which do not contain the leguminous micro-organisms.

Later experiments have shown that each kind of leguminous plant has its own kind of bacteria, and that those from another leguminous plant will not answer for inoculation purposes.

1 kebler, $1895: A \mathrm{~m} . J$. Pharm., 67, 602: Trowbridge, 7897 : This Joutual, 19, 328. 
The bacteria live upon the juices of the host, and in turn supply the plant with nitric nitrogen assimilated from the air in the soil, thus establishing a symbiosis. While the roots of all the leguminosæ show rather large quantities of nitric nitrogen, the question whether these bacteria furnish all the plant needs or more, has not been determined, so far as I know. If the micro-organisms should produce more nitric nitrogen than the plant needs for its growth, will not this excess help to feed a crop growing among the leguminose? In order to answer these questions small plots of ground of uniform character were planted in peas, peas and corn, corn, cotton and sorghum, and one plot was cultivated like the planted plots, and kept free from vegetation. Since soils produce nitrates by nitrification, and by the fixation of nitrogen from the atmosphere by means of soil bacteria, this "fallow" plot was the zero point for the measurement of the nitric nitrogen in the soil of the plots that were planted.

The soil was a rich bottom land and very productive. The analyses were made September 30 , after about six weeks of dry weather. This would allow the nitrates to accumulate, if formed in excess by the pea plants.

One kilogram of soil was taken about one foot from the plants, in several places, but towards the center of each plot. It was shaken for six hours with one liter of water, the suspended clay precipitated with five grams of sodium chloride, one-half liter decanted, evaporated to small bulk, and the nitric nitrogen estimated in duplicate by the Tiemann and Schulze method. The number of milligrams of nitric nitrogen in one kilo of soil is given for each plot below.

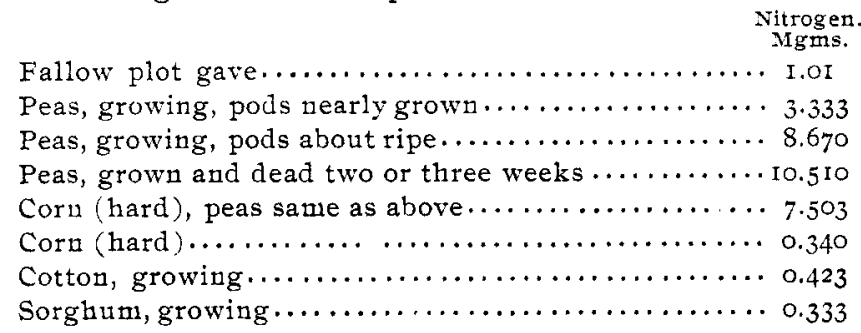

As was to be expected, practically no nitrates were found in 
the soil under the growing cotton and sorghum. But more nitrates were found under the growing peas than under the fallow plot, showing that the micro-organisms on the pea roots assimilate more nitrogen than the plant needs for its growth, and that this excess is found in the soil. With the ripening of the peas the excess of nitrates increased, indicating a continuance of the activity of the micro-organisms until the plant has ceased to grow. It may be that they continue to grow and assimilate nitrogen after the pea plant is dead-as long as there are juices in the plant. The larger quantities of nitric nitrogen in the soil where the peas were dead, over that where the pods were ripe, would tend to show this. But the bacteriologist only can answer this question. The fact that the corn and peas plot showed less nitrates than the pea plot of the same age, yet more than the fallow plot, shows that the growing corn had used some of the nitrates in its growth. Had the corn been growing at the time the samples were taken, there would doubtless have been found still less nitrates, as the "corn" plot, though the corn was about dead, showed practically no nitrates. This excess of nitrates in the corn and pea plot was therefore likely produced largely after the corn had ceased to grow.

These experiments indicate that peas planted with a crop would tend to increase the yield of that crop, unless the peas be so thick as to interfere with the crop's root development, or use up too much water in their growth.

Whether these results will hold good for all leguminosæ, or for peas in all kinds of seasons, only further investigations can determine. It is to be hoped that the agricultural chemists of the various experiment stations will take up this veryimportant line of work.

Georgia Normal aNd INdUStrial College.

\title{
PETROLEUM INCLUSION IN QUARTZ CRYSTALS. ${ }^{1}$
}

\author{
By Chas. L. Reese. \\ Received August 29, 1898 .
}

$7 \mathrm{HE}$ quartz crystals, of which an illustration is here given, are of interest on account of the size of the cavities and the quantity and character of the liquid in them.

1 Read at the Boston meeting of the American Chemical Society, August, 1898 . 